\title{
Article/Artigo
}

\section{Seroprevalence of hepatitis B virus infection and associated factors among prison inmates in State of Mato Grosso do Sul, Brazil}

\author{
Soroprevalência e fatores associados à infecção pelo vírus da hepatite B em população \\ encarcerada no Estado do Mato Grosso do Sul, Brasil
}

\begin{abstract}
Alcione Cavalheiro Faro Stief ${ }^{1}$, Regina Maria Bringel Martins ${ }^{2}$, Sônia Maria Oliveira de Andrade ${ }^{1}$, Mauricio Antonio Pompilio ${ }^{1}$, Sonia Maria Fernandes ${ }^{1}$, Paula Guerra Murat ${ }^{1}$, Gina Jonasson Mousquer ${ }^{1}$, Sheila Araújo Teles ${ }^{3}$, Graciele Rodrigues Camolez ${ }^{1}$, Roberta Barbosa Lopes Francisco ${ }^{4}$ and Ana Rita Coimbra Motta-Castro ${ }^{1}$
\end{abstract}

\begin{abstract}
Introduction: This study aimed to estimate the prevalence of HBV infection and associated factors among prison inmates in Campo Grande, MS. Methods: A total of 408 individuals were interviewed regarding sociodemographic characteristics, associated factors and HBV vaccination using a standardized questionnaire. Blood samples were collected from all participants and serological markers for $\mathrm{HBV}$ were detected by enzyme-linked immunosorbent assay. Hepatitis B surface antigen ( $\mathrm{HBsAg}$ ) and/or antibodies against hepatitis B core antigen (anti-HBc) positive samples were tested for $\mathrm{HBV}-\mathrm{DNA}$ by polymerase chain reaction. Results: The overall prevalence of HBV infection was 17.9\% (95\%CI: 14.4-22.0). The HBsAg carrier rate was $0.5 \%$; $56(13.7 \%)$ individuals had been infected and developed natural immunity and 15 (3.7\%) were positive for anti-HBc only. Ninety eight (24\%) prisoners had only anti-HBs, suggesting that they had low vaccine coverage. An occult $\mathrm{HBV}$ infection rate of $0 \%$ was verified among anti-HBc-positive individuals. Multivariate analysis of associated factors showed that age $>35$ years-old, low schooling level and illicit drug use are significantly associated with HBV infection. Conclusions: Analysis of the data showed HBV infection prevalence similar or slightly lower than that reported in other of Brazilian prisons. Independent predictors of HBV infection in this population include older age, low schooling level and illicit drug use.

Key-words: Hepatitis B. Prisoners. Prevalence. Associated factors.
\end{abstract}

\section{RESUMO}

Introdução: $O$ presente estudo teve como objetivo investigar a prevalência da infecção pelo HBV e os fatores associados a esta infecção em população encarcerada de Campo Grande, MS. Métodos: Quatrocentos e oito encarcerados, provenientes das populações encarceradas do Instituto Penal de Campo Grande, Presídio de Segurança Máxima e Presídio Feminino Irmã Irma Zorzi, foram entrevistados sobre dados sociodemográficos e fatores associados à infecção pelo HBV. A seguir foram coletadas amostras sanguíneas para detecção dos marcadores $\mathrm{HBsAg}$, anti-HBs e anti-HBc total por ensaio imunoenzimático. O HBV-DNA foi detectado pela reação em cadeia da polimerase nas amostras HBsAg e anti-HBc reagentes. Resultados: A prevalência global para infecção pelo HBV foi de 17,9\% (IC 95\%: 14,4-22,0), 13,7\% (56/408) para o anti-HBc total associado ao anti-HBs e em 15 (3,7\%) indivíduos foi detectada a presença do anti-HBc isolado. HBsAg foi encontrado em 0,5\% (2/408) dos indivíduos estudados, evidenciando uma baixa prevalência de casos crônicos. Em 24\% (98/408) dos indivíduos, verificou-se positividade isolada ao marcador anti-HBs, sugerindo baixa cobertura vacinal ao HBV. Após análise multivariada, ter idade maior que 35 anos, baixo nível de escolaridade e uso de droga ilícita permaneceram associados significativamente à infecção pelo HBV. Conclusões: A prevalência da infecção pelo HBV encontrada foi similar às reportadas em outros estudos conduzidos em populações encarceradas do Brasil. Os fatores de risco associados a esta infecção foram aumento da idade, baixo nível de escolaridade e uso de droga ilícita.

Palavras-chaves: Hepatite B. Encarcerados. Prevalência. Fatores associados.

1. Department of Biochemistry and Pharmacy, Federal University of Mato Grosso do Sul, Campo Grande, MS, Brazil. 2. Institute of Tropical Pathology and Public Health, Federal University of Goiás, Goiânia, GO, Brazil. 3. School of Nursing, Federal University of Goiás, Goiânia, GO, Brazil. 4. Central Public Health Laboratory, Campo Grande, MS, Brazil.

Address to: Dra Ana Rita Coimbra Motta-Castro. Depto de Farmácia e Bioquímica/UFMS. Av. Filinto Muller s/n, Campus Cidade Universitária, Caixa Postal 649, 74004-382 Campo Grande, MS, Brasil. Fax: $55673382-9687$

e-mail: arcm.castro@hotmail.com

Received in 04/11/2009

Accepted in 19/04/2010

\section{INTRODUCTION}

Despite the availability of effective vaccines, hepatitis $\mathrm{B}$ virus (HBV) infection remains a very important public health problem. Of the 2 billion people who have been infected with $\mathrm{HBV}$, it is estimated that there are still more than 350 million chronic carriers worldwide ${ }^{1}$.

Brazil is considered a country with intermediate prevalence, within which distinct geographical areas may present high or low incidence $e^{2,3,4}$.

Studies have reported that the prevalence of HBV infection is higher in the prison population than in the general population ${ }^{5,6}$. International studies show that the overall HBV infection ranges from $1.8 \%$ to $62 \%^{7-15}$ among adult inmates. Studies conducted with prisoners in Brazil determined HBV seroprevalence ranging from $11.1 \%$ to $26.4 \% 8,11,14,15$.

This population is considered to be at high risk of $\mathrm{HBV}$ infection due to the prison lifestyle, including illicit drug use, unsafe sex with multiple sexual partners, homosexuality and tattooing. In addition, the prison inmates are characterized by pervasive social health problems, illegal behavior and limited educational opportunities ${ }^{16,17}$. Due to the fact that prisoners suffer from lack of appropriate health care, the penal systems could serve as reservoirs for HBV. In addition, $\mathrm{HBV}$ infected inmates may also transmit this virus to the general population ${ }^{6,17}$.

Althoughknowledgeregardingthe epidemiological status of HBV infection among the prison population is important to identify specific risk factors in order to implement appropriate prevention measures ${ }^{9}$, few studies in this population have been conducted in $\mathrm{Brazi}^{8,11,15,18}$. Thus, the aim of this study was to investigate the prevalence and associated factors for $\mathrm{HBV}$ infection among prison inmates in the State of Mato Grosso do Sul. 


\section{METHODS}

A cross-sectional study was conducted in three jails of the capital Campo Grande, MS. This study was conducted in the only prison for females, Irmã Zorzi, with 395 prisoners and in two others for males: the Maximum Security Prison (Presídio de Segurança Máxima) and the Campo Grande Penal Institute (Instituto Penal de Campo Grande) with 1,455 prisoners.

The prisoners were advised that the survey was voluntary, anonymous and confidential. No inducements were offered and no negative sanctions were imposed on nonparticipants. After explanation of the purpose of the study, all the prisoners were invited to participate and $242(61.3 \%)$ women and $166(11.4 \%)$ men agreed to do so, following which free, informed consent was obtained. Participants answered a questionnaire with sociodemographic characteristics (age, sex, marital status, skin color, schooling level and family income), potential associated factors for HBV (prior surgery, previous blood transfusion, tattoos/piercings, acupuncture, condom use, number of sexual partners, illicit drug use, history of sexuallytransmitted disease), homosexual behavior and imprisonment) and previous hepatitis B vaccination.

\section{Serological tests}

Blood samples were collected from each participant and sera were stored at $-20^{\circ} \mathrm{C}$. Serum samples were tested to detect the following serological markers for HBV infection: HBsAg, antibodies against $\mathrm{HBsAg}$ (anti-HBs) and antibodies against hepatitis B core antigen (total anti-HBc and IgM anti-HBc). Samples that presented isolated reactivity for anti-HBc or $\mathrm{HBsAg}$ were retested. $\mathrm{HBsAg}$ positive samples were further tested for hepatitis $\mathrm{B}$ and antigen $(\mathrm{HBeAg})$ and antibodies against $\mathrm{HBeAg}$ (anti-HBe). These procedures were performed by enzyme-linked immunosorbent assays (ELISA, Bio-Rad, France).

\section{Viral DNA detection}

HBsAg and/or anti-HBc positive samples were submitted to DNA extraction using commercial kits (Invitrogen, Carlsbad, CA). The Pre$\mathrm{S} / \mathrm{S}$ genome region was amplified by a semi-nested polymerase chain reaction (snPCR), as described by Motta-Castro et $\mathrm{al}^{19}$.

\section{Data analysis}

For the purposes of analysis, a positive identification of $\mathrm{HBsAg}$ and/or anti-HBc markers was considered an indication of current or previous $\mathrm{HBV}$ infection. Vaccinated individuals (only anti-HBs reagent) were not included in the analysis. Prevalence and 95\% confidence intervals were calculated. The data were analyzed using the EPI-INFO 3.4.1 (Center for Diseases Control and Prevention, Atlanta, GA, USA, 1997) statistical software package. The Student t test (continuous variable), Chi square and Fisher exact tests (categorical variables) were used to compare variables and to evaluate associations between HBV positivity and associated factors. These data, estimated by the odds ratio in univariate analysis, were further analyzed with a stepwise logistic regression model to identify possible confounders. Statistical significance was assessed at the 0.05 probability level in all analyses. Statistical evaluations were performed using SPSS version 11.0 (SPSS inc, Chicago, USA, 1999).

\section{Ethical}

The protocol used in the present study was approved by the Human and Animal Research Ethics Committee of the Federal University of Mato Grosso do Sul.

\section{RESULTS}

Of the 408 inmates, 242 (59.3\%) were females and 166 (40.7\%) were males. Age ranged from 18 to 74 years-old (mean 26). Of the participants, $60.5 \%$ were white, $40.6 \%$ were single, $72.1 \%$ had received 8 years or less of formal education (fundamental education in Brazil), $44.5 \%$ reported a monthly income of US\$150 or less and $62.4 \%$ were born in the State of Mato Grosso do Sul.

To assess the prevalence of HBV serological markers in the study population, 408 individuals were analyzed (Table 1). The prevalence of any HBV serological marker was $17.9 \%$ (95\% CI: 14.4-22.0). Only two (0.5\%) individuals were $\mathrm{HBsAg}$ and anti-HBc total positive. Both were negative for IgM anti-HBc, indicating the absence of acute or recent infection in this population. Detection of total anti-HBc associated with anti-HBs was verified in 56 (13.7\%) individuals and suggested past infection with natural immunity. Anti-HBc alone was detected in 15 (3.7\%) individuals. Ninety eight (24\%) had serological evidence of $\mathrm{HBV}$ vaccination. The remaining population $(58.1 \%)$ lacked serological markers for HBV infection and was, thus, susceptible to HBV. Infection rates varied from $14 \%$ (prison for females) to $23.5 \%$ (prison for males).

TABLE 1 - Prevalence of the serological markers of the hepatitis B virus in prisoners in Campo Grande, State of Mato Grosso do Sul, Brazil ( $n=408$ ).

\begin{tabular}{lccccccc}
\hline & & \multicolumn{5}{c}{ Positive } & \\
\cline { 3 - 6 } Category infected & Serological markers & male & female & $n$ & $\%$ & $95 \%$ CI \\
\cline { 3 - 6 } & HBsAg/anti-HBc & 2 & 0 & 2 & 0.5 & $0.08-1.9$ \\
& anti-HBc only & 7 & 8 & 15 & 3.7 & $2.1-6.1$ \\
& anti-HBc/anti-HBs & 30 & 26 & 56 & 13.7 & $10.6-17.5$ \\
Vaccinated & any infection marker & 39 & 34 & 73 & 17.9 & $14.4-22.0$ \\
Susceptible & isolated anti-HBs & 20 & 78 & 98 & 24.0 & $20.0-28.5$ \\
\hline 95\%CI: 95\% confidence interval. & marker absence & 121 & 116 & 237 & 58.1 & $53.4-63.1$ \\
\hline
\end{tabular}

Hepatitis B virus-DNA was detected in the two $\mathrm{HBsAg} / \mathrm{anti}-\mathrm{HBc}$ positive individuals. One of them was also $\mathrm{HBeAg}$ positive. All anti$\mathrm{HBc}$ positive/HBsAg negative samples $(\mathrm{n}=71$ ) were HBV DNA negative, resulting an occult $\mathrm{HBV}$ infection rate of $0 \%$.

There was a significant association for anti-HBc prevalence with increasing age (Figure 1), rising from $12.9 \%$ in the $\leq 25$ years-old age group to $40 \%$ in those older than 45 years-old.

The prevalence of HBV markers was higher in men (23.5\%) than in women (14\%), although the difference was not statistically significant $(\mathrm{p}>0.05)$ (Table 2).

In the univariate analysis, age $>35$ years-old, low schooling level, drug use, prior surgery, previous blood transfusion, history of STD and imprisonment more than three times were associated with HBV infection. The term drug use refers to any illicit drug, injectable and non-injectable. These variables were included in a logistic regression model. After controlling for potential confounders, HBV exposure was independently associated with age $>35$ years-old (36 to 45 year-old-group: $\mathrm{OR}=3.5$; $95 \% \mathrm{CI}$ : $1.4-8.7$ and $>45$-year-old-group: $\mathrm{OR}=4.1 ; 95 \% \mathrm{CI}: 1.3-12.1$ ), low schooling level (1-8 years: $\mathrm{OR}=3.1$; $95 \% \mathrm{CI}: 1.3-7.3$ and illiteracy: $\mathrm{OR}=11.7 ; 95 \% \mathrm{CI}: 2.5-55.2)$ and drug use (OR $=2.2$; 95\%CI: 1.1-4.4) (Table 2). 


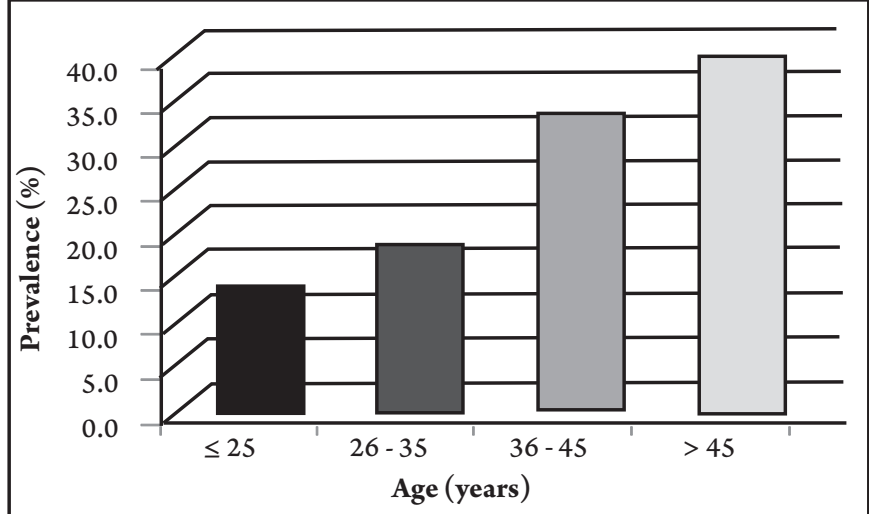

FIGURE 1 - Prevalence (\%) of anti-HBc according to age, among prisoners in Campo Grande, State of Mato Grosso do Sul, Brazil ( $n=408)$.

TABLE 2 - Factors associated with hepatitis B virus infection among prisoners in Campo Grande, State of Mato Grosso do Sul, Brazil ( $n=310)$.

\begin{tabular}{|c|c|c|c|c|c|c|}
\hline Factors & $\begin{array}{c}\text { HBV } \\
\text { Pos./total }\end{array}$ & $\%$ & $\begin{array}{c}\text { Odds ratio } \\
\text { crude } \\
(95 \% \mathrm{CI})\end{array}$ & $\mathrm{p}$ & $\begin{array}{l}\text { Odds ratio } \\
\text { adjusted* } \\
(95 \% \mathrm{CI})\end{array}$ & $\mathrm{p}$ \\
\hline \multicolumn{7}{|l|}{ Sex } \\
\hline female & $34 / 164$ & 20.7 & 1.0 & & 1.0 & \\
\hline male & $39 / 146$ & 26.7 & $1.4(0.8-2.3)$ & $>0.05$ & $1.2(0.6-2.4)$ & $>0.05$ \\
\hline
\end{tabular}

\section{Age (years)}

$\begin{array}{lllll}\leq 25 & 9 / 70 & 12.9 & 1.0 & 1.0\end{array}$

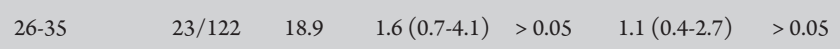

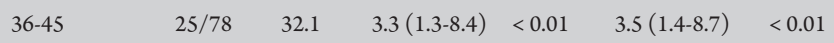

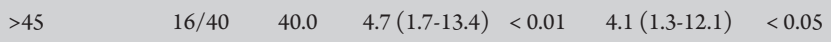

Schooling (years)

$1-8$

$10 / 81$

12.3

1.0

1.0

none

$54 / 211$

$25.62 .4(1.1-5.4)<0.05$

$3.1(1.3-7.3)<0.01$

NI 5

\begin{tabular}{lllclcl}
\hline $\begin{array}{l}\text { Drug use } \\
\text { no }\end{array}$ & $17 / 113$ & 15.0 & 1.0 & & & \\
yes & $55 / 193$ & 28.5 & $2.2(1.2-4.1)$ & $<0.01$ & $2.2(1.1-4.4)$ & $<0.05$ \\
NI 5 & & & & & & \\
\hline
\end{tabular}

Surgery

no

yes

NI 2

\begin{tabular}{|c|c|c|c|c|c|c|}
\hline \\
\hline \multicolumn{7}{|c|}{$\begin{array}{l}\text { Blood transfusion } \\
\text { no } 48 / 242\end{array}$} \\
\hline yes & $22 / 61$ & 36.1 & $2.3(1.2-4.2)$ & $<0.01$ & $1.2(0.5-2.5)$ & $>0.05$ \\
\hline NI 1 & & & & & & \\
\hline
\end{tabular}

STD

$\begin{array}{lllclcl}\text { no } & 35 / 194 & 18.0 & 1.0 & 1.0 & & \\ \text { yes } & 37 / 108 & 34.3 & 2.4(1.4-4.1) & <0.01 & 1.4(0.7-2.7) & >0.05 \\ \text { NI } 9 & & & & & & \end{array}$

\begin{tabular}{lcccccc}
\hline \multicolumn{2}{l}{ Imprisonments (n) } & & & & & \\
1 & $30 / 158$ & 19.0 & 1.0 & 1.0 & \\
2 & $18 / 72$ & 25.0 & $1.4(0.7-2.9)$ & $>0.05$ & $1.7(0.8-3.7)$ & $>0.05$ \\
$\geq 3$ & $25 / 80$ & 31.3 & $1.9(1.0-3.4)$ & $<0.05$ & $1.1(0.5-2.5)$ & $>0.05$ \\
\hline
\end{tabular}

NI: no information, 95\%CI: 95\% confidence interval, STD: sexually transmitted diseases, *adjusted for sex, age, schooling level, drug use, prior surgery, previous blood transfusion, history of STD, homosexual behavior and number of imprisonments.

\section{DISCUSSION}

The prevalence of any HBV serological marker verified among these prisoners (17.9\%) was similar to that reported for inmates in Ribeirão Preto, São Paulo $(19.5 \%)^{15}$, Salvador, Bahia $(11.1 \%)^{14}$ and Manhuaçu, Minas Gerais (17.5\%) ${ }^{11}$. In addition, the prevalence among prisoners analyzed in this paper is higher than those reported in other countries, such as England, Ireland and Germany, where prevalence rates of $7 \%, 8.7 \%, 3.9 \%$ were determined, respectively ${ }^{5,9,10}$. These data demonstrate that $\mathrm{HBV}$ infection is a significant problem among prisoners.

In contrast, only $0.5 \%$ (2/408) of prisoners were HBV carriers, since they were HBsAg-reactive, which makes it less likely, but not impossible that this virus is transmitted in prison. This prevalence was similar to values obtained in a population-based multicentric study conducted in the capital cities of the Northeast, Central-West and Federal Districts ${ }^{20}$. However, when occult hepatitis B infection was investigated, all anti-HBc positive individuals were HBV DNA negative.

Only 98 (24\%) individuals presented serological evidence of a previous $\mathrm{HBV}$ vaccination and 58\% (237/408) were susceptible to this infection. This low vaccination coverage and the high number of susceptible individuals suggest that this is an extremely useful opportunity to ensure access to healthcare services, education programs and the implementation of vaccination programs to prevent HBV infection. A valuable strategy could be immunization against hepatitis $\mathrm{B}$ at admission into prison.

Multivariate analysis of associated factors showed that age greater than 35 years-old, low schooling level and drug use are significantly associated with $\mathrm{HBV}$ infection. As observed elsewhere ${ }^{21-23}$, older age was associated with this infection. Age may be a proxy for lifetime exposure, indicating that, over time, there is a cumulative risk of HBV infection linked to sexual activity and percutaneous exposures.

A study conducted by Human Rights Watch (1998) indicates that the level of education among inmates in the Brazilian prisons is low, especially among the younger inmates, among whom many have never attended school on a regular basis. In fact, more than $70 \%$ of inmates in the present study had less than eight years of schooling, reflecting difficult access to school, or more probably, early dropout. Illiteracy, reported by some of the participants, was strong associated with $\mathrm{HBV}$ infection in multivariate analysis. This result is in agreement with findings from other studies ${ }^{19,23,25,26}$.

Illicit drug use was highly frequent among the prisoners investigated and was independently associated with $\mathrm{HBV}$ infection. This practice has been reported elsewhere and may be a surrogate marker for other high risk behaviors ${ }^{7,12}$. In the case of injecting drug users, HBV may be easily transmitted by sharing needles. Among non-injecting drug users, several types of paraphernalia were shared to consume drugs, but no study has reported these as significantly associated with the risk of $\mathrm{HBV}$ infection ${ }^{27,28}$. Moreover, having unprotected sex when under the influence of drugs showed an increased risk of becoming HBV-infected ${ }^{27}$.

Sexual promiscuity has been associated with HBV infection in the adult population ${ }^{29}$. In this study, history of STD was associated with this infection in univariate analysis, as well as the number of imprisonments, indicating the possibility of $\mathrm{HBV}$ transmission inside prisons and suggesting that measures to minimize the spread of this virus are essential. 
Some limitations regarding the study should be highlighted. Selfreporting of $\mathrm{HBV}$ vaccination was not accurate, because more than half of the prisoners did not remember whether they had been vaccinated or not. It was also impossible to distinguish between injectable and non-injectable drug users. The final sample has a lower number of males compared with the total population due to the limited access to male jails for safety reasons. Despite the methodological limitations that prevent generalization, these findings are in agreement with other studies.

The present investigation is the first report concerning the epidemiology of HBV infection in prisoners in Mato Grosso do Sul, Central Brazil and the results highlight the high vulnerability to hepatitis B infection in this population. Further epidemiological studies in male prisons are required to provide up-to-date information regarding the health status of inmates and to plan preventive strategies adapted to the profiles of this specific population.

In conclusion, the global $\mathrm{HBV}$ prevalence of $17.9 \%$ verified among prisoners was similar to that reported in other studies. Only $0.5 \%$ of the prisoners were $\mathrm{HBV}$ carriers, $13.7 \%$ had been infected and developed natural immunity, $3.7 \%$ were anti-HBc alone and $24 \%$ were anti-HBs alone, suggesting that they had been administered a HBV vaccination. Among all risk factors studied, increased age, low schooling level and drug use were independently and positively associated with HBV markers.

\section{ACKNOWLEDGMENTS}

The authors would like to thank the participating prisoners, authorities and staff of the collaborating detention centers for making this survey possible. The authors are also grateful to Rita de Cássia Palhares Benevides for her valuable assistance with the laboratory work.

\section{CONFLICT OF INTEREST}

The authors declare that there is no conflict of interest.

\section{FINANCIAL SUPPORT}

This study was supported by the Fundação de Apoio ao Desenvolvimento do Ensino, Ciência e Tecnologia do Estado de Mato Grosso do Sul (FUNDECT/MS).

\section{REFERENCES}

1. Liaw YF, Chu CM. Hepatitis B virus infection. Lancet 2009; 373:582-592.

2. Viana S, Parana R, Moreira RC, Compri AC, Macedo V. High prevalence of hapatitis B vírus and hepatitis D virus in the western Brasilian Amazon. Am J Trop Med Hyg 2005; 73:808-814.

3. Souto FJD. Distribuição da hepatite B no Brasil: atualização do mapa epidemiológico e proposições para seu controle. Gastroenterol Endosc Digest 1999; 18:143-150.

4. Tanaka J. Hepatitis B epidemiology in Latin America. Vaccine 2000; 18:17-19.

5. Weild AR, Gill ON, Bennett D, Levingstone SJM, ParryJV, Curran. Prevalence of HIV, hepatitis B, and hepatitis C antibodies in prisoners in England and Wales: a national survey. Commun Dis Public Health 2000; 3:121-126.

6. Javadi AA, Avijgan M, Hafizi M. Prevalence of $\mathrm{HBV}$ and $\mathrm{HCV}$ infections and associated risk factors in addict prisoners. Iranian J Publ Health 2006; 35:33-36.

7. DeckerMD, Vaugh WA, BrodieJS, Hutcheson RH, SchaffnerW. Seroepidemiology of hepatitis B in Tenessee prisoners. J Infect Dis 1984; 150:450-459.
8. Martelli CMT, Andrade ALLS, Cardoso DDP, Sousa LCS, Silva SA, Sousa MA, et al. Soroprevalência e fatores de risco para a infecção pelo vírus da hepatite B pelos marcadores AgHBs e anti-HBs em prisioneiros e primodoadores de sangue. Rev Saude Publica 1990; 24:270-276.

9. Stark K, Bienzle U, Vonk R, Guggenmoos-Holzmann I. History of syringe sharing in prison and risk of hepatitis B virus, and human immunodeficiency virus infection among injecting drug users in Berlin. Int J Epidemiol 1997; 26:1359-1366.

10. Allwright S, Bradley F, Long J, Barry J, Thornton L, Parry JV. Prevalence of antibodies to hepatitis B, hepatitis $\mathrm{C}$, and HIV and risk factors in entrants to Irish prisons: results of a national cross sectional survey. BMJ 2000; 321:78-82.

11. Catalan-Soares BC, Almeida RTP, Carneiro-Proietti ABF. Prevalence of HIV-1/2, HTLV-I/II, hepatitis B vírus (HBV) e C (HCV), do Treponema pallidum and Trypanosoma cruzi entre presidiários em Manhuaçu, Minas Gerais State, Brazil. Rev Soc Bras Med Trop 2000; 33:27-30.

12. Babudieri S, Longo B, Sarmati L, Starnini G, Dori L, Suligoi B, et al. Correlates of HIV, HVB, and HCV infections in a prison inmate population: results form a multicentre study in Italy. J Med Virol 2005; 76:311-317.

13. Thomas AR, Keene WE, Cieslak PR. Seroprevalence of hepatitis B and C in juvenile detention entrants, Oregon, 1994-1996. J Adolesc Health 2005; 37:411-414.

14. Fialho M, Messias M, Page-Shafer K, Farre L, Schmalb M, Pedral-Sampaio D, et al. Prevalence and risk of blood-borne and sexually transmitted viral infections in incarcerated youth in Salvador, Brazil: opportunity and obligation for intervetion. AIDS Behav 2008; 12 (suppl 4): S17-24.

15. Coelho HC, Oliveira SAN, Miguel JC, Oliveira MLA, Figueiredo JFC, Perdoná GC, et al. Soroprevalência da infecção pelo vírus da hepatite B em uma prisão brasileira. Rev. Bras. Epidemiol 2009; 12:124-131.

16. Awofeso N. Hepatitis B vaccination in prisons. Bull World Health Organ 2002; 80:569-574

17. Macalino EG, Viahov D, Sanford-Colby S, Patel S, Sabin K, Salas C. Prevalence and incidence of HIV, hepatitis $\mathrm{B}$ virus, and hepatitis $\mathrm{C}$ virus infections among males in Rhode Island prisons. Am J Public Health 2004; 94:1218-1223.

18. Osti NM, Pestana de Castro AF, Ricci LC. Research of antigen and antibodies from retroviruses, $\mathrm{CMV}$ and $\mathrm{HBV}$ among prisoners of the penitentiary complex of the region of Campinas, SP, Brazil. Rev Inst Med Trop São Paulo 1998; 40:209-213.

19. Motta-Castro ARC, Martins RMB, Yoshida CFT, Teles AS, Paniago AM Lima KMB, et al. Hepatitis B virus infection in isolated Afro-Brazilian communities. J Med Virol 2005; 77:188-193.

20. Leila MMB, Pereira CMT, Martelli EMH, Ulisses R, Montarroyos MLC, Lima MRA, et al. Population-Based Multicentric Survey of Hepatitis B Infection and Risk Factor Differences among Three Regions in Brazil. Am J Trop Med Hyg 2009; 81:240-247.

21. Motta-Castro ARC, Yoshida CFT, Lemos CRS, Oliveira JM, Cunha RV Lewis-Ximenes LL, et al. Seroprevalence of hepatitis B virus infection among an Afro-descendent community in Brazil. Mem Inst Oswaldo Cruz 2003; 98:13-17.

22. Souza MG, Passos ADC, Machado AA, Figueiredo JFC, Esmeraldino LE $\mathrm{HIV}$ and hepatitis B virus co-infection: prevalence and risk factors. Rev Soc Bras Med Trop 2004; 37:391-395.

23. Matos MAD, Reis NRS, Klozlowki AG, Teles AS, Motta- Castro ARC, Mello FCA et al. Epidemiological study of hepatitis A, B and C in the largest Afro-Brazilian isolated community. Trans R Soc Trop Med Hyg 2009; 103:899-905.

24. Human Rights Watch (HRW). O Brasil atrás das grades, 1998. Disponível em <http://hrw.org/portuguese/reports/presos/>. Acesso em: 15 de agosto 2008.

25. Adjei AA, Armah HB, Gbagbo F, Ampofo WK, Boamah, Adu-Gyamfi C, et al Correlates of HIV, HBV, $\mathrm{HCV}$ and syphilis infections among prison inmates and officers in Ghana: a national multicenter study. BMC Infect Dis 2008; 7:33.

26. Matos MA, Martins RMB, França DDS, Pessoni GC, Ferreira RC, Matos MAD, et al. Epidemiology of hepatitis B infection in truck drivers in Brazil, South America. Sex Transm Infect 2008; 84:386-389.

27. Rossi D, Radulich G, Muzzio E, Naveira J, Sosa-Estani S, Rey J, et al. Multiple infections and associated risk factors among non-injecting cocaine users in Argentina. Cad Saude Publica 2008; 24:965-974.

28. Gyarmathy VA, Neaigus A, Miller M, Friedman SR, Des Jarlais DC. Risk correlates os prevalent HIV, hepatitis $B$ virus, and hepatitis $C$ virus infection among non-injecting heroin users. J Acquir Immune Defic Syndr 2002; 30(suppl 4):448-456.

29. Rosenblum L, Darrow W, Witte J, Cohen J, French J, Sikes K, et al. Sexual practices in the transmission of hepatitis B virus and prevalence of hepatitis Delta virus infection in female prostitutes in the United States. JAMA 1992; 267:2477-2481. 